\title{
Predictive Value of Neutrophil/Lymphocyte Ratios in the Diagnosis of Acute Appendicitis
}

\section{Akut Apandisit Tanısında Nötrofil/Lenfosit Oranlarının Prediktif Değeri}

\author{
Muhammet Akyüz ${ }^{1 \oplus}$, Uğur Topal ${ }^{2} \oplus$, Mustafa Gök ${ }^{1 \oplus}$, Bahadır Öz ${ }^{1 \oplus}$ \\ Şadi Yenel İsaoğulları ${ }^{1 \oplus}$, Erdoğan Mütevelli Sözüer ${ }^{2} \oplus$ \\ ${ }^{1}$ Department of General Surgery, Erciyes University Medical Faculty, Kayseri, Turkey \\ ${ }^{2}$ Department of Surgical Oncology, Erciyes University Medical Faculty, Kayseri, Turkey
}

Received: 04 March 2020 / Accepted: 09 March 2020 / Publication date: 26 March 2020

Cite as: Akyüz M, Topal U, Gök M, Öz B, İsaoğulları ŞY, Sözüer EM. Predictive value of neutrophil/lymphocyte ratios in the diagnosis of acute appendicitis. Med J Bakirkoy 2020;16(1):76-84.

\begin{abstract}
Objective: The debate on the value of laboratory tests in the diagnosis of acute appendicitis (AA) continues. In this study, we aimed to evaluate the blood count parameters and the diagnostic value of neutrophil/lymphocyte ratio in the diagnosis of acute appendicitis.

Method: 851 patients who underwent appendectomy under emergency conditions were included in the study. Patients were divided into 2 groups; Group 1 was negative appendectomy and Group 2 was acute appendicitis. In addition, they were divided into subgroups as 18-39 years, $40-59$ years, and 60 years and older. Neutrophil, platelet, lymphocyte count and Neutrophil/lymphocyte ratio were compared in groups and subgroups.

Results: There were 146 patients (17.1\%) in Group 1 (negative appendectomy group) and 705 patients (82.9\%) in Group 2 (acute appendicitis group). Male sex was dominant in Group $2(p=0.049)$. Neutrophil count and neutrophil / lymphocyte ratio (NLR) were higher in Group 2 $(p<0.001, p<0.001$, respectively), whereas in Group 1, lymphocyte count and platelet count were higher $(p=0.008, p=0.002$, respectively). The cutoff value for NLR was found to be 5.29 in the ROC curve analysis. In this value, NLR sensitivity was found as $57.3 \%$, specificity as $69.9 \%$, positive predictive value as $57,1 \%$, negative predictive value as $69,2 \%$. Multivariate analysis showed that the risk of acute appendicitis was 6.71 times higher in patients with NLR 15.29 (OR: $6.71+0.28 ; 95 \%$ Cl: 6,150-7,276; $p=0.024$ ). In subgroups, the cut-off point for NLR was 5.10 for 18-39 years; 6.63 for $40-59$ years; and 5.80 for 60 years and older. The highest sensitivity for these cut-off points was in the age group of 60 and over with $69 \%$, while the highest specificity was in the $40-59$ years age group with $58.2 \%$.

Conclusion: Although the sensitivity and specificity of neutrophil /lymphocyte ratio (NLR) varies according to age groups, it is a useful and helpful parameter for physical examination and other diagnostic methods in the diagnosis of acute appendicitis.
\end{abstract}

Keywords: neutrophil-to-lymphocyte ratio, acute appendicitis, diagnosis

öz

Amaç: Bu çalışmada akut apandisit tanısı koymada kan sayımı parametreleri ve nötrofil/lenfosit oranının tanısal değerini değerlendirmeyi amaçladık.

Yöntem: Acil şartlarda appendektomi yapılan 851 hasta çalışmaya dahil edildi. Postoperatif patoloji bulhusuna göre hastalar Grup 1 negatif appendektomi; Grup 2 akut apandisit olmak üzere iki gruba ayrıldı. Ayrıca 18-39, 40-59, 60 yaş ve üstü olmak üzere subgruplara ayrıldı. Nötrofil, platelet, lenfosit sayısı ve Nötrofil/lenfosit oranı gruplarda ve subgruplarda karșılaștıııldı. $p<0,05$ değeri istatistiksel olarak anlamlı kabul edildi.

Bulgular: Grup 1 negatif appendektomi grubunda de 146 hasta \%17,1 Grup 2 akut apandisit grubunda 705 hasta \%82,9 yer alıyordu. Grup 2 de erkek cinsiyet baskındı $p=0,049$. Grup 2'de nötrofil sayısı $p<0,001$ ve nötrofil/ lenfosit oranı (NLO) $p<0,001$ daha yüksek iken Grup 1'de lenfosit sayısı $p=0,008$ ve platelet sayısı $p=0,002$ daha yükek bulundu. NLOiçin (ROC) eğrisi analizinde kesme noktası 5,29 bulundu. Bu değerde NLO sensitivesi \%57.3, spesifitesi \%69,9 pozitif prediktif değerini \%57,1 negatif prediktif değeri \%69,2 bulundu. Multivartant analizde NLO $\geq 5,29$ olan olgularda akut apandisit riskinin 6,71 kat daha yüksek olduğu saptandı (OR: 6,71+0,28; 95\% Cl: 6, 150-7, 276; $p=0,024)$. Sub gruplarda NLO için kesme noktası 18-39 için 5, 10; $40-59$ için 6,63 ve 60 yaş ve üzeri için 5,80 bulundu. Bu kesme noktaları için en yüksek sensivite $\% 69$ ile 60 yaş ve üzeri grupta iken en yüksek spesivite \%58,2 ile 40-59 yaş grubunda bulundu.

Sonuç: Nötrofil/lenfosit oranının (NLO) sensivitesi ve spesivitesi yaş gruplarına bağlı olarak değişmekle birlikte; akut apandisit tanısı koymada fizik muayene ve diğer tanısal yöntemlere yardıma ve kullanışlı bir parametredir.

Anahtar kelimeler: nötrofil/Lenfosit oranı, akut apandisit, teşhis

Corresponding Author:

sutopal2005@hotmail.com
M. Akyüz 0000-0002-2002-8698

U. Topal 0000-0003-1305-2056

M. Gök 0000-0003-4272-1087
B. Öz 0000-0002-3791-0521

Ş. Y. İsaoğulları 0000-0003-3767-7317 E. M. Sözüer 0000-0002-3332-2570

(C) Telif hakkı Sağlık Bilimleri Üniversitesi Bakırköy Dr. Sadi Konuk Eğitim ve Araştırma Hastanesi'ne aittir. Logos Tıp Yayıncılık tarafindan yayınlanmaktadır. Bu dergide yayınlanan bütün makaleler Creative Commons Attf-GayriTicari 4.0 Uluslararası Lisansı ile lisanslanmıştır.

(c) Copyright Health Sciences University Bakırköy Sadi Konuk Training and Research Hospital. This journal published by Logos Medical Publishing.

Licenced by Creative Commons Attribution-NonCommercial 4.0 International (CC BY-NC 4.0) 


\section{INTRODUCTION}

The most common cause of acute abdomen requiring surgical intervention is acute appendicitis (AA) globally ${ }^{(1)}$. Approximately $8 \%$ of the general population in Western countries undergo appendectomy during their lifetime ${ }^{(2)}$. The overall incidence of perforated appendicitis in cases with acute appendicitis is $4-39 \%$, and the rate of negative appendectomy in patients operated for acute appendicitis is reported to be $9-15 \%$ in the literature ${ }^{(3-6)}$.

The diagnosis of acute appendicitis is still difficult when it's only based on clinical and laboratory data. Pathologies of gastrointestinal, urological or gynecological origin mimicking acute appendicitis make diagnosis even more difficult in adult patients. There is no laboratory marker which can distinguish AA by itself, from various other etiologies of abdominal pain ${ }^{(7)}$.

Delay in diagnosis leads to perforation and thus increased morbidity rates, while negative appendectomy rates increase with premature decisions to perform surgery ${ }^{(8)}$. To increase early detection of acute appendicitis and reduce misdiagnosis rates, researchers have used many parameters. Erythrocyte sedimentation rate (ESR), white blood cell (WBC) count, C-reactive protein (CRP) and bilirubin levels, immature granulocyte ratio and neutrophil / lymphocyte ratio (NLR) are some of them ${ }^{(2,9,10)}$.

The physiological response of leukocytes to inflammation increases neutrophil and decreases lymphocyte counts Therefore, the ratios of these leukocyte subsets (neutrophil / lymphocyte ratio) can be used as an important marker of inflammation ${ }^{(7,11)}$.

Goodman etal. demonstrated neutrophil-lymphocyte ratio (NLR) as a diagnostic tool for the first time, and when this ratio was greater than 3.5, they found that it was significant in diagnosing acute appendicitis ${ }^{(12)}$. In the following years, many authors have reported that the neutrophil / lymphocyte ratio (NLR) is a marker of inflammation and found it to have a preoperative diagnostic parameter in $\mathrm{AA}^{(13-15)}$.

Kahramanca et al. associated a $4.68 \mathrm{NLR}$ value with acute appendicitis $(p<0.001)$. The sensitivity, specifi- city, negative (NPV), and positive predictive values (PPV) of this cut-off value were $65.3 \%-54.7 \%, 23.0 \%$, and $88.4 \%$ respectively ${ }^{(13)}$.

With this study, we aimed to determine the diagnostic value of NLR in the diagnosis of acute appendicitis.

\section{MATERIAL and METHOD}

The study included 851 patients who were surgically treated for acute appendicitis between January 2013 and January 2019 at Erciyes University Faculty of Medicine General Surgery Clinic. 12.06.2019 dated and numbered Approval was received from the local Ethics Committee. (date: 06. 12. 2019 decision no. 2019/431) Patient files and records of the hospital information system were reviewed and a database was created. Using this database, cases were analyzed retrospectively. The diagnosis of acute appendicitis was made based on physical examination, medical history, and supporting laboratory values and radiological findings. Patients who underwent appendectomy with the diagnosis of acute appendicitis and their pathology reports were included in the study. Patients under 18 years of age, pregnants, patients with a chronic inflammatory disease (tuberculosis, sarcoidosis), an autoimmune disease, hematologic disease, patients using steroids, pathological tumors and those whose records couldn't be reached were excluded from the study.

Based on histopathological evaluation, the patients were divided into 2 groups as Group 1 (negative appendectomy patients), and Group 2 (acute appendicitis patients). The basic demographic data (age, sex) and preoperative laboratory findings (lymphocyte count $/ \mathrm{mm}^{3}$, neutrophil count $/ \mathrm{mm}^{3}$, platelet count $/ \mathrm{mm}^{3}$, and neutrophil/lymphocyte ratio (NLR)) were compared between Groups 1 and 2. Additionally, Groups 1 and 2 were divided into 3 subgroups by age; as subgroups of patients aged 18-39, 40-59, and $\geq 60$ years. The same parameters were compared between the age subgroups.

The total blood count was measured using an automated hematology analyzer (Roche Hitachi Cobas ${ }^{\circledR}$ 8000 Roche Diagnostics, Indianapolis, IN, USA). The NLR was calculated for each patient by dividing neutrophil counts by lymphocyte counts 


\section{Statistical Analysis}

The data were analyzed using the IBM SPSS Statistics for Windows, version 24 package program (IBM Corp., Armonk, N.Y., USA). Descriptive statistical methods (mean, standard deviation, median, frequency, ratio, minimum, maximum) as well as the Student's t test were used to compare quantitative data, and the Mann Whitney $U$ test was used for the evaluation of the non-normally distributed neutrophil / lymphocyte ratios. For the comparison of qualitative data, Pearson's chi-square test and Fisher's exact test were used. Multivariate logistic regression tanalysis was also employed. The diagnostic accuracy was evaluated and examined using receiver operating characteristic (ROC) curve analysis. The appropriate cut-off values were identified, and the specificity, sensitivity, positive, and negative predictive values, positive, and negative likelihood ratios were calculated for the parameters with an area under the curve (AUC) value of above 0.600. $p<0.05$ value was considered statistically significant.
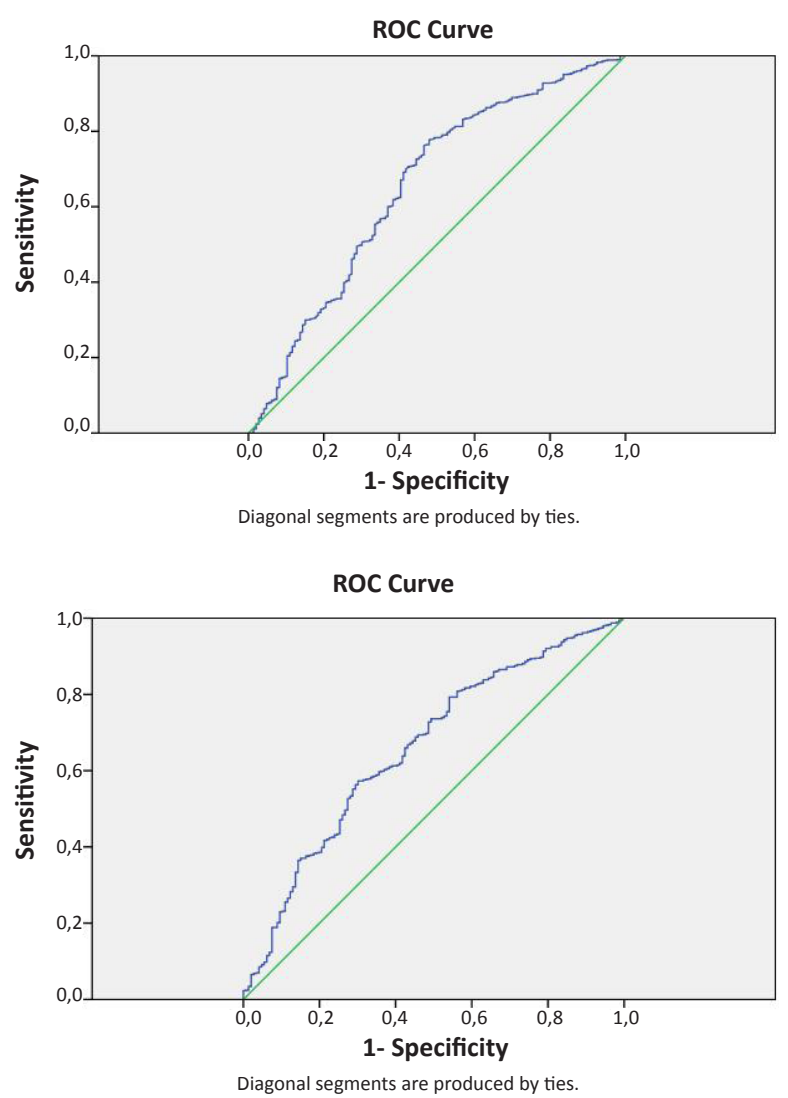

\section{RESULTS}

A total of 851 patients were included in the study. The negative appendectomy group (Group 1) consisted of 146 and the acute appendicitis group (Group 2) consisted of 705 patients. The mean age of the patients was $33.6 \pm 13.7$ years in Group 1; and $35.4 \pm 15.1$ in Group $2(p=0.184)$. Sex distribution was equal in Group 1, while male patients constituted $57.9 \%$ of the patient population in Group 2. In univariate analyses, neutrophil, lymphocyte, platelet counts and NLR values were found to be significantly different between the two groups. These parameters were determined to be independent variables in the diagnosis of acute appendicitis in multivariate logistic regression analysis. The comparison between Groups 1 and 2 is detailed in Table 1 . In the ROC curve analyses of these independent variables, AUC was above 0.600 for the neutrophil count and NLR (Figure 1). The proposed cut-off values and the performance characteristics of these variables are detailed in Table 2. When the patients were subgrouped by
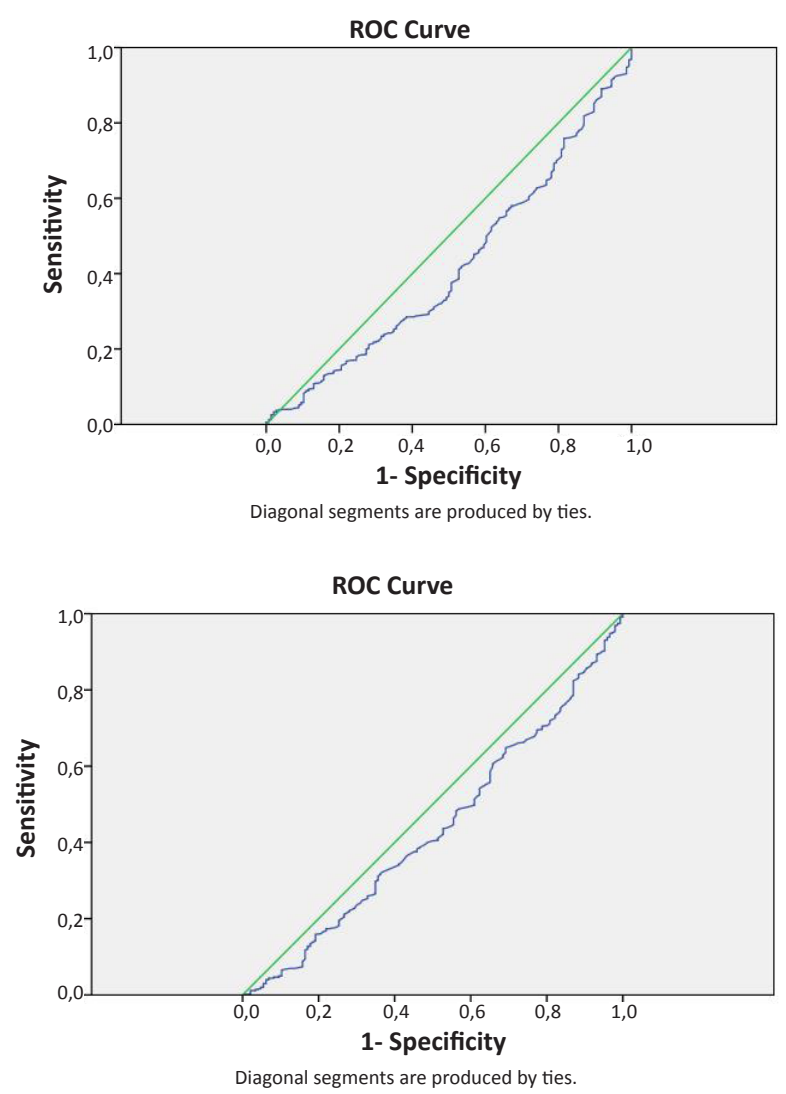

Figure 1. Receiver operating characteristic (ROC) curve analyses of significant parameters for the diagnosis of acute appendicitis: (a) Neutrophil count (b) Lymphocyte count (c) Neutrophil/lymphocyte ratio (NLR), (d) Platelet count. 


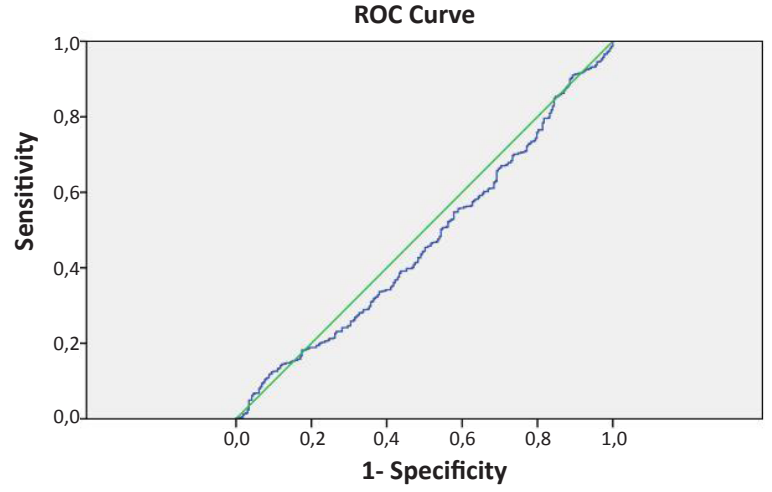

Diagonal segments are produced by ties.

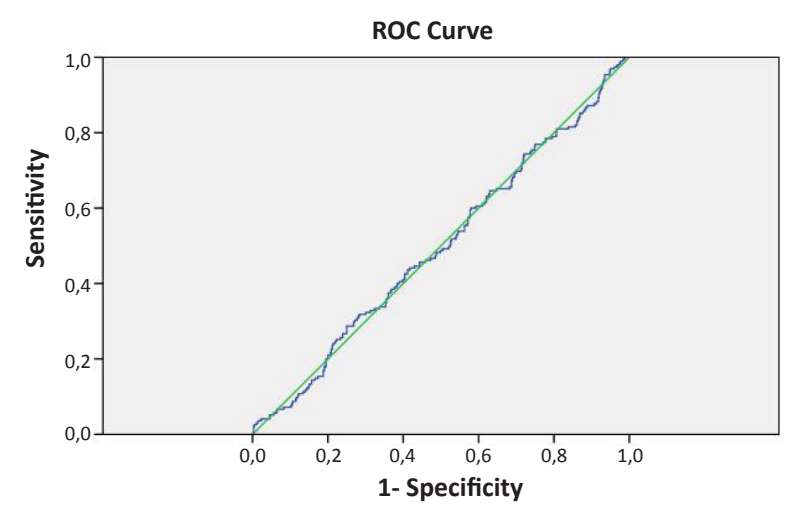

Diagonal segments are produced by ties.

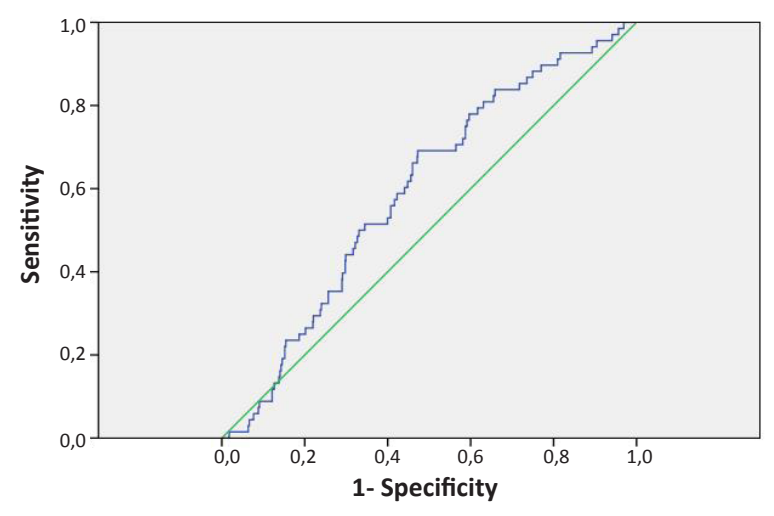

Figure 2. Receiver operating characteristic (ROC) curve analyses of NLR for the diagnosis of acute appendicitis in the age subgroups.

Table 1. Comparison of the two groups.

\begin{tabular}{|c|c|c|c|c|c|c|c|c|c|}
\hline \multirow[b]{2}{*}{ Parameters } & \multicolumn{3}{|c|}{ Univariate analysis } & \multicolumn{3}{|c|}{ Multivariate analysis } & \multicolumn{3}{|c|}{ Roc curve analysis } \\
\hline & $\begin{array}{c}\text { Negative } \\
\text { appendectomy }\end{array}$ & $\begin{array}{c}\text { Acute } \\
\text { appendicitis }\end{array}$ & $\mathbf{p}$ & OR & $\begin{array}{c}95 \% \mathrm{Cl} \\
\text { (min-max) }\end{array}$ & $\mathbf{p}$ & AUC & $\begin{array}{c}95 \% \mathrm{Cl} \\
\text { (min-max) }\end{array}$ & $\mathbf{p}$ \\
\hline Patient number & 146 & 705 & & & & & & & \\
\hline Age & $\begin{array}{c}33,6+13,7 \\
(18-85)\end{array}$ & $\begin{array}{c}35,4+15,1 \\
(18-87)\end{array}$ & 0,184 & & & & & & \\
\hline $\begin{array}{l}\text { Sex } \\
\quad \text { Male } \\
\text { Female }\end{array}$ & $\begin{array}{l}73(50,0) \\
73(50,0)\end{array}$ & $\begin{array}{l}408(57,9) \\
297(42,1)\end{array}$ & 0,049 & & & & & & \\
\hline Neutrophil $\left(\times 10^{3} / \mathrm{mm}^{3}\right)$ & $\begin{array}{c}8,2+4,5 \\
(1,31-29,16)\end{array}$ & $\begin{array}{c}10,1+3,9 \\
(1,75-23,83)\end{array}$ & 0,000 & $9,21+0,18$ & $8,850-9,570$ & 0,033 & 0,654 & $0,602-0,706$ & 0,000 \\
\hline Lymphocyte $\left(\times 10^{3} / \mathrm{mm}^{3}\right)$ & $\begin{array}{c}1,95+0,8 \\
(0,51-4,81)\end{array}$ & $\begin{array}{c}1,74+0,8 \\
(0,26-7,29)\end{array}$ & 0,008 & $1,84+0,04$ & $1,771-1,927$ & 0,008 & 0,419 & $0,36-0,469$ & 0,002 \\
\hline NLR & $\begin{array}{c}5,39+4,7 \\
(0,52-26,08)\end{array}$ & $\begin{array}{c}8,03+6,5 \\
(0,72-48,46)\end{array}$ & 0,000 & $6,71+0,28$ & $6,150-7,276$ & 0,024 & 0,660 & $0,611-0,709$ & 0,000 \\
\hline $\mathrm{PLT}\left(\mathrm{x} 10^{3} / \mathrm{mm}^{3}\right)$ & $\begin{array}{c}267,2+94,7 \\
(92-810)\end{array}$ & $\begin{array}{c}245,5+73,4 \\
(64-758)\end{array}$ & 0,002 & $256,38+3,52$ & $249,46-263,29$ & 0,011 & 0,436 & $0,386-0,487$ & 0,016 \\
\hline
\end{tabular}

Neutrophil-to lymphocyte ratio (NLR), PLT: Platelet count, AUC: Area under the curve, OR: Odds ratio 
Table 2. Proposed cut-off values for significant parameters in the diagnosis of acute appendicitis.

\begin{tabular}{|c|c|c|c|c|c|c|c|c|c|}
\hline & Cut-off value & Sensitivity (\%) & Specificity (\%) & PPV & NPV & OR & pLLR & nLRR & AUC \\
\hline Neutrophil $\left(\times 10^{3} / \mathrm{mm}^{3}\right)$ & 8,04 & 70,1 & 58,2 & 69,1 & 58,1 & 6,14 & 1,24 & 0,38 & 0,654 \\
\hline Lymphocyte $\left(\times 10^{3} / \mathrm{mm}^{3}\right)$ & 1,57 & 52,3 & 38,4 & 51,2 & 38,3 & 1,25 & 0,93 & 1,37 & 0,419 \\
\hline NLR & 5,29 & 57,3 & 69,9 & 57,1 & 69,2 & 4,55 & 1,20 & 0,39 & 0,660 \\
\hline $\mathrm{PLT}\left(\mathrm{x} 10^{3} / \mathrm{mm}^{3}\right)$ & 238,5 & 48,2 & 43,8 & 47,3 & 55,4 & 1,21 & 0,94 & 1,29 & 0,436 \\
\hline
\end{tabular}

Neutrophil-to-lymphocyte ratio (NLR), PLT: Platelet count, AUC: Area under the curve,PPV: Positive predictive value; NPV: Negative predictive value; OR: Odds ratio; $p L L R$ : Positive likelihood ratio; nLLR: Negative likelihood ratio

Table 3. Comparison of the subgroups.

\begin{tabular}{|c|c|c|c|c|c|c|c|c|c|c|}
\hline \multirow[b]{2}{*}{ Parameters } & \multicolumn{4}{|c|}{ Univariate analysis } & \multicolumn{3}{|c|}{ Multivariate analysis } & \multicolumn{3}{|c|}{ Roc curve analysis } \\
\hline & $18-39$ & $40-59$ & 60 and older & $\mathbf{p}$ & OR & $\begin{array}{c}95 \% \mathrm{Cl} \\
\text { (min-max) }\end{array}$ & p & AUC & $\begin{array}{c}95 \% \mathrm{Cl} \\
\text { (min-max) }\end{array}$ & p \\
\hline Patient number & 588 & 195 & 68 & & & & & & & \\
\hline \multicolumn{11}{|l|}{ Age } \\
\hline $\begin{array}{l}\text { Sex } \\
\quad \text { Male } \\
\text { Female }\end{array}$ & $\begin{array}{l}332(56,5) \\
256(43,5)\end{array}$ & $\begin{array}{l}113(57,9) \\
82(42,1)\end{array}$ & $\begin{array}{l}36(52,9) \\
32(47,1)\end{array}$ & 0,772 & & & & & & \\
\hline $\begin{array}{l}\text { Neutrophil } \\
\left(\times 10^{3} / \mathrm{mm}^{3}\right)\end{array}$ & $\begin{array}{c}10,1+4,1 \\
(1,31-29,16)\end{array}$ & $\begin{array}{c}9,2+3,9 \\
(1,59-23,07)\end{array}$ & $\begin{array}{c}9,2+3,6 \\
(2,38-16,29)\end{array}$ & 0,024 & $9,5+0,2$ & $9,173-9,958$ & 0,009 & $\begin{array}{l}0,559 \\
0,445 \\
0,460\end{array}$ & $\begin{array}{l}0,519-0,600 \\
0,400-0,490 \\
0,391-0,529\end{array}$ & $\begin{array}{l}0,006 \\
0,019 \\
0,273\end{array}$ \\
\hline $\begin{array}{l}\text { Lymphocyte } \\
\left(\times 10^{3} / \mathrm{mm}^{3}\right)\end{array}$ & $\begin{array}{c}1,85+0,8 \\
(0,34-7,29)\end{array}$ & $\begin{array}{c}1,69+0,8 \\
(0,26-6,59)\end{array}$ & $\begin{array}{c}1,38+0,6 \\
(0,35-3,56)\end{array}$ & 0,000 & $1,64+0,04$ & $1,562-1,729$ & 0,023 & $\begin{array}{l}0,581 \\
0,464 \\
0,351 \\
\end{array}$ & $\begin{array}{l}0,540-0,622 \\
0,418-0,510 \\
0,288-0,415 \\
\end{array}$ & $\begin{array}{l}0,000 \\
0,125 \\
0,000 \\
\end{array}$ \\
\hline NLR & $\begin{array}{c}7,4+6,2 \\
(0,52-48,46)\end{array}$ & $\begin{array}{c}7,7+7,1 \\
(1,13-47,64)\end{array}$ & $\begin{array}{c}8,2+4,7 \\
(1,34-26,78)\end{array}$ & 0,568 & $7,8+3,1$ & $7,203-8,429$ & 0,001 & $\begin{array}{l}0,469 \\
0,498 \\
0,594\end{array}$ & $\begin{array}{l}0,428-0,511 \\
0,452-0,544 \\
0,530-0,658\end{array}$ & $\begin{array}{l}0,152 \\
0,934 \\
0,010\end{array}$ \\
\hline PLT $\left(x 10^{3} / \mathrm{mm}^{3}\right)$ & $\begin{array}{c}248,0+70,8 \\
(64-810)\end{array}$ & $\begin{array}{c}254,8+90,6 \\
(98-758)\end{array}$ & $\begin{array}{c}243,5+95 \\
(75,2-629)\end{array}$ & 0,464 & $248,8+3,8$ & $241,33-256,29$ & 0,002 & $\begin{array}{c}0,509 \\
0,509 \\
0,45\end{array}$ & $\begin{array}{l}0,466-0,553 \\
0,462-0,556 \\
0,371-0,532\end{array}$ & $\begin{array}{l}0,665 \\
0,702 \\
0,183\end{array}$ \\
\hline
\end{tabular}

Neutrophil-to-lymphocyte ratio (NLR), PLT: Platelet count,AUC: Area under the curve,OR: Odds ratio

Table 4. Proposed cut-off values for NLR in diagnosis of acute appendicitis to age groups.

\begin{tabular}{|c|c|c|c|c|c|c|c|c|c|}
\hline Age Groups & Cut-off value & Sensitivity (\%) & Specificity (\%) & PPV & NPV & OR & pLLR & nLRR & AUC \\
\hline $18-39$ & 5,10 & 54,8 & 42,2 & 54,1 & 41,1 & 6,44 & 0,95 & 1,10 & 0,469 \\
\hline $40-59$ & 6,63 & 44,1 & 58,2 & 44,3 & 57,1 & 5,99 & 0,89 & 0,81 & 0,498 \\
\hline 60 and older & 5,80 & 69,1 & 52,7 & 70,2 & 52,3 & 13,49 & 2,40 & 0,92 & 0,594 \\
\hline
\end{tabular}

Neutrophil-to-lymphocyte ratio (NLR), AUC: Area under the curve,PPV: Positive predictive value; NPV: Negative predictive value; OR: Odds ratio; pLLR: Positive likelihood ratio; nLLR: Negative likelihood ratio 
age, there were 588 patients aged 18-39, 195 patients aged 40-59, and 68 patients aged 60 years and older. Male sex dominance was present in all age subgroups. In univariate analyzes for age subgroups, lymphocyte and neutrophil counts were significantly different between groups. In multivariate logistic regression analysis, neutrophil, lymphocyte, platelet counts and NLR were independent variables in the diagnosis of acute appendicitis. The comparison between the subgroups by age is given in Table 4. In the ROC curve analyses of these independent variables in age subgroups, an AUC above 0.600 was not determined. The results of ROC curve analysis for NLR in age subgroups iare given in Figure 2. The proposed cut-off values and performance characteristics for NLR in age subgroups are shown in Table 4.

\section{DISCUSSION}

Early diagnosis of acute appendicitis may not always be possible. Making the decision to observe a patient until a clear diagnosis can be made or to operate prematurely to prevent undesirable complications such as perforation and peritonitis represents a very serious dilemma for surgeons ${ }^{(13,16)}$.

In general, finding suitable, easily accessible and cost-effective diagnostic markers for early detection of diseases has always been the focus of interest of researchers. Many markers that can be used for early diagnosis were investigated because of morbidity and mortality caused by delayed diagnosis in patients followed up for acute abdominal pain in the emergency departments $(9,10,13,17)$.

The diagnosis of acute appendicitis, even in this modern era, is still a problem. A combination of physical examination, certain laboratory tests and a number of imaging studies are used for definitive diagnosis. There are several diagnostic tests which are used for appendicitis, including leukocyte count, percentage of neutrophils, C-reactive protein (CRP), procalcitonin and D-Dimer ${ }^{(18-20)}$.

Complete blood count is an easily accessible and rapidly evaluated test in the emergency department. Neutrophil, leukocyte, lymphocyte, and platelet counts, and neutrophil-lymphocyte ratio in complete blood counts have been investigated in various stu- dies as markers of inflammation ${ }^{(7,9,10,13,14)}$.

However, there is no single laboratory test or imaging method with $100 \%$ diagnostic sensitivity for acute appendicitis.

The mean age of the patients included in our study did not differ statistically between the groups. In accordance with the studies in the literature, male sex was dominant in the acute appendicitis group and male/female ratio was similar in the negative appendectomy group ${ }^{(9,13,17)}$. The negative appendectomy rate was $19.7 \%$ in female patients. We think that this rate is higher than male patients because of the gynecological causes of pelvic pain mimicking acute appendicitis symptoms.

In studies investigating the diagnostic value of NLR, for negative appendectomy was reported to be between $12.9-18.5 \%{ }^{(8,9,13,17,21)}$. In our series, this rate was found to be $17.1 \%$.

Complete blood count is an important component of diagnosis in patients with suspected acute appendicitis. Although leukocyte count generally increases in patients with acute appendicitis, it is not a specific marker for acute appendicitis and may increase in many diseases associated with other inflammatory conditions considered during differential diagnosis. In acute appendicitis, neutrophilia and a left shift in hemogram are often associated with lymphopenia (21,22). In a meta-analysis (neutrophil count> 6500 / $\mathrm{mm}^{3}$ ), Anderson reported a sensitivity of $71-89 \%$ and specificity of $48-80 \%{ }^{(21)}$. In our study, the neutrophil count was found to be higher in the acute appendicitis group $(p=0,000)$. The cut-off value determined according to the ROC curve analysis was found to have $70 \%$ specificity and $58 \%$ specificity (AUC: 0.654 (95\% Cl: 0.602-0.706) $p=0.000)$ ).

N. Boshnak et al. found low lymphocyte count as a risk factor in both univariate and multivariate analyses. When they determined the lymphocyte count (OR: 0.0125; 95\% Cl: 0.0015-0.1031; p<.001) cut-off value as $2.3 \times 10^{9} / \mathrm{L}$, they found the sensitivity (82.76\%), specificity (63.64\%), positive (85.7\%), negative $(58.3 \%)$ predictive values as indicated. In the same study, the mean platelet counts in the groups with acute appendicitis, and negative appendec- 
tomy were found to be 109 / L 237.45 \pm 54.08 and $257.00 \pm 48.55$, respectively $(p=0.02)$. When the cutoff value for the platelet count was taken as $188 \times 109$ $\times / L$, they found the sensitivity ( $31.03 \%$ ), specificity $(100 \%)$, positive $(100 \%)$, and negative $(35.5 \%)$ predictive values as indicated ${ }^{233}$. In our study, the lymphocyte count was lower in the acute appendicitis group when compared to the negative appendectomy group $(p=0.008)$. Multivariate analysis (OR: $1.84+0 ; 95 \% \mathrm{Cl}: 1.771-1.927 ; \mathrm{p}=.008) \times 10^{3} / \mathrm{mm}^{3}$ showed a sensitivity of $52.3 \%$, a specificity of $38 \%$, a positive predictive value of $51,2 \%$ and a negative predictive value of $38,3 \%$ when the cut-off value was taken as $1,57 \times 10^{3} / \mathrm{mm}^{3}$. Platelet counts were higher in the negative appendectomy group $(p=0.002)$. Multivariate analysis (OR: $256.38+3.52 ; 95 \% \mathrm{Cl}$ : 249.46-263.29; $\mathrm{p}=0.011$ ) showed a sensitivity of $48.2 \%$, a specificity of $43.8 \%$, a positive predictive value of $47.3 \%$ and a negative predictive value of $55.4 \%$ when the cut-off value was taken as $1.57 \times 10^{3} /$ $\mathrm{mm}^{3}$. Although there are contradictory views regarding platelet counts in acute appendicitis and complicated appendicitis, our series were similar to that of N. Boshnak et al ${ }^{(24-26)}$.

The physiological response of leukocytes to stress is manifested as increased neutrophil, but decreased lymphocyte counts. Therefore, the ratio of these two parameters to each other is used as a marker of inflammation. During the inflammatory response, the ratio of leukocytes in the circulatory system changes. The increase in neutrophils is accompanied by relative lymphopenia. NLR can be claimed as a simple indicator of inflammatory response ${ }^{(27)}$. The evaluation of NLR can give us information regarding two different immune pathways simultaneously and it is also indicative of the body's overall inflammatory state. First, neutrophils responsible for inflammation and second, lymphocytes has a regulatory function (28). Previous studies have shown that NLR may be significant in a variety of clinical situations and is a robust diagnostic marker of acute appendicitis $(12,13,27,29)$.

Goodman et al. first suggested NLR as a potential diagnostic tool and they found it to be significant for diagnosing acute appendicitis when this value was greater than $3.5^{(15)}$. Many studies in the literature have reported preoperative NLR to be a useful para- meter that helps diagnose acute appendicitis and differentiates between uncomplicated and complicated appendicitis ${ }^{(9,12,13,21)}$. In contrast, Aktimur et al. found that NLR did not differ significantly between patients with positive and negative appendectomy (26).

Shimizu et al. recommends 5.0 as an cut-off value for NLR, with $44 \%$ sensitivity and $22 \%$ specificity for acute appendicitis.(30) Sevinç et al. reported an NLR cut-off value of 3.0 with a sensitivity of $81 \%$, and specificity of $53 \%$ for the diagnosis of acute appendicitis and a cut-off value of 5.5 with a sensitivity of $78.4 \%$, and a specificity of $4.1 \%$ for the diagnosis of perforated appendicitis ${ }^{(9)}$. Kahramanca et al. reported in their series of 1067 cases that the preoperatively measured NLR cut-off value was 4.68 and it was statistically related with the detection of acute appendicitis. They found the sensitivity of NLR as $65.3 \%$, specificity as $54.7 \%$, a positive predictive value of $88.4 \%$, and a negative predictive value of $23 \%{ }^{(13)}$. In our study, NLR was found to be statistically significant for diagnosing acute appendicitis in the univariate $(p=0.000)$ and multivariate analyses $(p=0.024)$. The sensitivity and specificity of NLR were calculated as $57.3 \%$ and $69.9 \%$, respectively, and the positive predictive value was $57.1 \%$ while the negative predictive value was $69.2 \%$. In our study, the risk of acute appendicitis was 6.71 times higher in cases with NLRs $\geq 5.29$ (OR: 6.71+0.28; 95\% Cl: 6.150$7.276 ; p=0.024)$.

We explain these sensitivity and specificity values which are rather low, by the inclusion of only patients who were operated on, in this study, as previously mentioned in the literature. We believe that the data on other suspected cases that were not operated on, or medically treated were not known, which could be the source of this finding ${ }^{(13)}$.

It has been reported that as the severity of appendiceal inflammation increases, lymphocyte counts decrease greatly in addition to neutrophilia. Consequently, NLR increases as appendicitis progresses to appendiceal gangrene and subsequent perforation ${ }^{(21,31)}$. Sevinç et al. found the cut-off value as 3 for NLR. The rate of complicated appendicitis was $6.5 \%$ in their series ${ }^{(9)}$. In our series, we concluded that the cut-off value was higher than the series 
cited in the literature, which was related to the fact that the rate of complicated appendicitis in our acute appendicitis patients was higher than the literature. Indeed, in $10 \%$ of the patients had complicated appendicitis. Despite conflicting recommendations in the literature regarding cut-off values, we believe that NLR is an important diagnostic parameter.

There are limited number of studies in the literature regarding the diagnostic value of NLR in different age subgroups. Yavuz et al. found in their study that for the ROC curve for NLR; the sensitivity was $92.5 \%$ while the specificity was $59.3 \%$ when the cut-off value was taken as 3.93 ; the sensitivity was $87.5 \%$ and the specificity was $63 \%$ when the cut-off value was taken as 4.51 ; and the sensitivity was $85 \%$ while the specificity was found to be $64.2 \%$ when the cutoff value was taken as 4.64. They found that diagnostic values for diagnosing acute appendicitis were increased when the cut-off value decreased (32). Cigsar et al. found the cut-off value of NLR as 4.9 by the evaluation of ROC curve analysis in their series, the sensitivity and specificity were found to be $73 \%$ ${ }^{(33)}$. In our study, when the cut-off value was taken as 5.80 in the group of patients who were aged 60 years and older, the sensitivity was found to be $69.1 \%$, specificity was $52.7 \%$, the positive predictive value was $70.2 \%$ and the negative predictive value was calculated as $52.3 \%$. The highest sensitivity for these cut-off values was detected in the age subgroup of 60 and over (69\%), while the highest specificity was found in the $40-59$ years age subgroup (58.2\%).

The most important limitation of our study was that it was designed retrospectively. In addition, only appendectomy patients were included in the study; the patients who were suspected of acute appendicitis and followed up with medical treatment were excluded. However, our patient population was wider than the series in the literature. We believe that our study provides comprehensive data on the diagnostic accuracy of simple laboratory parameters in the suspicion of acute appendicitis, and this study contributes to the literature with useful and valuable reference data.

In conclusion, an NLR value of 5.29 seems to be a reliable parameter to help us diagnose acute appendicitis. Although sensitivity and specificity of NLR varies according to age subgroups, we have found the highest sensitivity in patients aged 60 years and older and the highest specificity in patients aged 40-59 years. However estimation of NLR value alone is not sufficient for the diagnosis of acute appendicitis, and normal NLR values alone cannot exclude acute appendicitis. The clinical evaluation of the surgeon should continue to be a priority in diagnosing acute appendicitis. In order to determine the diagnostic accuracy of NLR, further prospective randomized trials are needed.

Ethics Committee Approval: Erciyes University Faculty of Medicine General Surgery Clinic. 12.06.2019 dated and numbered Approval was received from the local Ethics Committee (date: 06. 12. 2019 decision no. 2019/431).

Conflict of Interest: There is no conflict of interest.

Funding: There are no financial supports.

Informed Consent: Because the study was retrospective, patient consent could not be obtained.

\section{REFERENCES}

1. Ünal Y. A new and early marker in the diagnosis of acute complicated appendicitis: immature granulocytes. Ulus Travma Acil Cerrahi Derg. 2018;24:434-9. https://doi.org/10.5505/tjtes.2018.91661

2. Nshuti R, Kruger D, Luvhengo TE. Clinical presentation of acute appendicitis in adults at the Chris Hani Baragwanath Academic Hospital. Int J Emerg Med. 2014;7:12. https://doi.org/10.1186/1865-1380-7-12

3. Bulut T, Arduçoğlu Merter A. 2376 Apendektomi materyalinin retrospektif analizi. F.Ü. Sağ. Bil. Tıp Derg. 2017;31(3):105-9.

4. Birnbaum BA, Wilson SR. Appendicitis at the Millennium. Radiology. 2000;215:337-48. https://doi.org/10.1148/radiology.215.2.r00ma24337

5. Öones K, Peña AA, Dunn EL, et al. Are negative appendectomies still acceptable? Am J Surg;188(6):748-54. https://doi.org/10.1016/j.amjsurg.2004.08.044

6. Flum DR, Morris A, Koepsell T, Dellinger EP. Has misdiagnosis of appendicitis decreased over time?: A population-based analysis. JAMA. 2001;286(14):1748-53. https://doi.org/10.1001/jama.286.14.1748

7. Küçük $E$. The change of neutrophil lymphocyte ratio in acute appendicitis. Med-Science. 2015;4:2379-87. https://doi.org/10.5455/medscience.2015.04.8265

8. Eryılmaz R, Şahin M, Alimoğlu O, Baş G, Özkan OV. Negatif apendektomileri Önlemede c-reaktif protein lökosit sayımının değeri. Ulus Travma Acil Cerrahi Derg. 2011;7:142-5.

9. Sevinç MM, Kınacı E, Çakar E, Bayrak S, Özakay A, Aren A, et al. Diagnostic value of basic laboratory parameters for simple and perforated acute appendicitis: An analysis of 3392 cases. Ulus Travma Acil Cerrahi Derg. 2016;22:155-62. https://doi.org/10.5505/tjtes.2016.54388

10. McGoran DR, Sims HM, Zia K, Uheba M, Shaikh IA. The value of biochemical markers in predicting a perforation in acute appendicitis. ANZ J Surg. 2013;83:79-83. https://doi.org/10.1111/ans.12032

11. Berridge MJ. Cell stress, inflammatory responses and cell 
death. BJ Signal. 2012;11:1-29.

12. Goodman DA, Goodman CB, Monk JS. Use of the neutrophil: Lymphocyte ratio in the diagnosis of appendicitis. Am Surg. 1995;61(3):257-9.

13. Kahramanca S, Ozgehan G, Seker D, et al. Neutrophil-tolymphocyte ratio as a predictor of acute appendicitis. Ulus Travma Acil Cerrahi Derg. 2014;20:19-22. https://doi.org/10.5505/tjtes.2014.20688

14. Khan A, Riaz M, Kelly ME, Khan W, Waldron R, Barry K, et al. Prospective validation of neutrophil-to-lymphocyte ratio as a diagnostic and management adjunct in acute appendicitis. Ir J Med Sci. 2018;187(2):379-84. https://doi.org/10.1007/s11845-017-1667-z

15. Jung SK, Rhee DY, Lee WJ, et al. Neutrophil-to-lymphocyte count ratio is associated with perforated appendicitis in elderly patients of emergency department. Aging Clin Exp Res. 2017;29:529-36. https://doi.org/10.1007/s40520-016-0584-8

16. Schellekens DH, Hulsewé KW, van Acker BA, van Bijnen AA, de Jaegere TM, Sastrowijoto $\mathrm{SH}$, et al. Evaluation of the diagnostic accuracy of plasma markers for early diagnosis in patients suspected for acute appendicitis. Acad Emerg Med. 2013;20:703-10 https://doi.org/10.1111/acem.12160

17. Kapci M, Turkdogan KA, Duman A, et al. Biomarkers in the diagnosis of acute appendicitis. JCEI. 2014;5:250-5. https://doi.org/10.5799/ahinjs.01.2014.02.0397

18. Şahbaz NA, Bat O, Kaya B, Ulukent SC, Illkgül Ö, Özgün MY, et al. The clinical value of leucocyte count and neutrophil percentage in diagnosing uncomplicated (simple) appendicitis and predicting complicated appendicitis. Ulus Travma Acil Cerrahi Derg. 2014;20:423-6. https://doi.org/10.5505/tjtes.2014.75044

19. Yokoyama S, Takifuji K, Hotta T, Matsuda K, Nasu T, Nakamori $M$, et al. C-Reactive protein is an independent surgical indication marker for appendicitis: A retrospective study. World J Emerg Surg. 2009;4:36. https://doi.org/10.1186/1749-7922-4-36

20. Mentes O, Eryilmaz M, Harlak A, Ozer T, Balkan M, Kozak O, et al. Can D-dimer become a new diagnostic parameter for acute appendicitis? Am J Emerg Med. 2009;27:765-9. https://doi.org/10.1016/j.ajem.2008.06.001

21. Eren T, Tombalak E, Burcu B, et al. Akut apandisit olgularında nötrofil/lenfosit oranının tanıda ve hastalığın şiddetini belirlemedeki prediktif değeri. Dicle Tıp Dergisi. 2016;43(2):279-84.

22. Andersson RE. Meta-analysis of the clinical and laboratory diagnosis of appendicitis. Br J Surg. 2004;91:28-37.

https://doi.org/10.1002/bjs.4464

23. Boshnak N, Boshnaq M, Elgohary H. Evaluation of platelet indices and red cell distribution width as new biomarkers for the diagnosis of acute appendicitis. J Invest Surg. 2018;31(2):121-9. https://doi.org/10.1080/08941939.2017.1284964

24. Aydogan A, Akkucuk S, Arica S, et al. The analysis of mean platelet volume and platelet distribution width levels in appendicitis. Indian J Surg. 2015;77:495-500. https://doi.org/10.1007/s12262-013-0891-7

25. Kilıc TY, Yesilaras M, Karaali C, et al. Diagnostic value of mean platelet volume in acute appendicitis. J Clin Anal Med. 2016;7:368-70. https://doi.org/10.4328/JCAM.3426

26. Aktimur R, Cetinkunar S, Yildirim K, et al. Mean platelet volume is a significant biomarker in the differential diagnosis of acute appendicitis. Inf Cell Sig. 2015;2:e930.

27. Zahorec R. Ratio of neutrophil to lymphocyte counts-Rapid and simple parameter of systemic inflammation and stress in critically ill. Bratisl Lek Listy. 2001;102:5-14.

28. Rahimirad S, Ghaffary MR, Rahimirad MH, Rashidi F. Association between admission neutrophil to lymphocyte ratio and outcomes in patients with acute exacerbation of chronic obstructive pulmonary disease. Tuberk Toraks. 2017;65(1):25-31. https://doi.org/10.5578/tt.27626

29. Ateş F, Yaraş S, Sarıtaş B, Altıntaş E, Sezgin O, Orekici G. Does neutrophil to lymphocyte ratio in peripheral blood predict endoscopic erosive esophagitis? Endoscopy. 2011;19:88-90.

30. Shimizu T, Ishizuka M, Kubota K. A lower neutrophil to lymphocyte ratio is closely associated with catarrhal appendicitis versus severe appendicitis. Surg Today. 2016;46:84-9. https://doi.org/10.1007/s00595-015-1125-3

31. Goulart RN, Silvério Gde S, Moreira MB, Franzon O. Main findings in laboratory tests diagnosis of acute appendicitis: A prospective evaluation. Arq Bras Cir Dig. 2012;25(2):88-90. https://doi.org/10.1590/S0102-67202012000200005

32. Yavuz E, Ercetin C, Uysal E, et al. Diagnostic value of neutrophil/lymphocyte ratio in geriatric cases with appendicitis. Turk J Geriatr. 2014;17(4):345-9.

33. Cigsar G, Yildirim AC, Anuk T, Guzel H, Gunal E, Gulkan S, et al. Neutrophil to lymphocyte ratio on appendectomy of geriatric and nongeriatric patients. J Investig Surg. 2017;30(5):285-90. https://doi.org/10.1080/08941939.2016.1241324 